\title{
Education and development projects in Brazil, 1932-2004: a critique
}

\author{
Educação e projetos de desenvolvimento \\ no Brasil, 1932-2004: uma crítica
}

THOMAS H. KANG*,**;***

RESUMO: A $2^{\text {a }}$ Lei de Diretrizes e Bases da Educação Nacional (2 ${ }^{\text {nd }}$ LDB), promulgada em 1971, mudou a configuração dos níveis de ensino no Brasil. Essa mudança tornou difícil a construção de uma base de dados confiável para o século XX. Trabalhos anteriores sobre a história econômica da educação no Brasil utilizaram dados da dissertação de Maduro (2007). Wjuniski (2013) usou essa base de dados e realizou testes de quebra estrutural. Ele concluiu que o governo brasileiro investiu pouco na expansão do ensino secundário. Entretanto, Wjuniski não considerou alguns problemas como: (i) a confiabilidade dos dados e (ii) os efeitos da $2^{\underline{a}}$ LDB nos dados de despesa em educação. Este artigo mostra que os dados de gasto educacional no Brasil não nos permitem afirmar que houve uma queda nos gastos com o ensino secundário com a mudança da lei após 1971.

PALAVRAS-CHAVE: História econômica; financiamento educacional; gasto com educação; economia política da educação.

ABSTRACT: The Second National Education Regulatory Framework (2 ${ }^{\text {nd }}$ LDB), enacted in 1971, changed the grade configuration of schooling levels in Brazil. This change made it challenging to construct a valid and reliable education spending data profile for $20^{\text {th }}$ century Brazil. Previous work on the economic history of education in Brazil used the data provided according to the thesis of Maduro (2007). Wjuniski (2013) used that database and ran structural break tests and concluded that the Brazilian government underinvested in the expansion of secondary education. However, Wjuniski did not consider problems concerning: (i) data reliability and (ii) the effects of the $2^{\text {nd }} \mathrm{LDB}$ on education expenditure

\footnotetext{
* Professor da Escola Superior de Propaganda e Marketing - SUL. Porto Alegre-RS, Brasil. E-mail: kang. thomas@gmail.com. Submitted: 28/November/2017; Approved: 8/March/2018.

** Ph.D. candidate, Programa de Pós-Graduação em Economia, Universidade Federal do Rio Grande do Sul - UFRGS, Porto Alegre-RS, Brasil.

$* * *$ I thank Flavio Comim, Fernando Cruz, Sergio Monteiro, Hudson Torrent, and Julia Martins for comments. I also acknowledge the contributions of the participants at the IV Workshop em Historia Econômica at FEA/USP in 2017, especially Renato Colistete, Bernardo Wjuniski, Ricardo Sabbadini, William Summerhill, and Samuel Pessôa. I am particularly indebted to Paulo Maduro and Ed Varejão, who provided me the dataset. Jim Hesson revised the English and textual conventions of this paper. The usual disclaimer applies.
} 
data. This paper shows that data on education spending in Brazil does not allow us to assert that there was an underinvestment in secondary education from 1971 onwards.

KEYWORDS: Economic history; education finance; education spending; political economy of education.

JEL Classification: N36; I22; I25.

\section{INTRODUCTION}

In a paper published in the Brazilian Journal of Political Economy, Wjuniski (2013) attempts to explain why Brazilian education lagged behind other countries throughout the $20^{\text {th }}$ century. His explanation is not a new one: Brazilian elites had little interest in expanding mass education and gave priority to higher education, as other scholars have also suggested (Plank, 1996; Plank et al.., 1996; Brown, 2002; Schwartzman, 2004; Valle Silva, 2008; Ansell, 2010; Kosack, 2012; Kang, 2011, 2017). The novelty of his approach comes from his methodology: the author uses previously compiled data on education spending and tries to detect structural breaks through an econometric test proposed by Bai and Perron $(1998,2003)$. After detecting the breakpoints, he relates those years to specific historical episodes. The author concludes that policies carried out by the Brazilian governments would have led to resource misallocation, particularly to the detriment of the secondary education level from 1971 onwards.

Even though I agree with the overall argument of Wjuniski (2013) as to why Brazilian education remained backwards, issues related to data and methodology raise important questions. First, the database comes from the M.A. thesis of Maduro (2007), who accessed the information available over several years of the Anuário Estatístico do Brasil (AEBs), the Brazilian Statistical Yearbook published by the Instituto Brasileiro de Geografia e Estatística. He then created a dataset on enrollments and education spending from 1932 to 2004. Bearing in mind the computation of human capital stocks, Maduro (2007) estimated many figures to fill in missing data from the original sources. Since interpolations tend to smooth out the data series, questions on data reliability arise if many gaps are filled in in this manner - especially for purposes other than growth empirics (such as testing structural breaks, which is the case here).

The second criticism holds even if the database is accurate given how the data is categorized. Using Maduro's database (2007), Wjuniski (2013) found several structural breaks in all schooling levels, including breakpoints for both primary and secondary levels around 1971. According to the author, the Second National Education Regulatory Framework ( $2^{a}$ Lei de Diretrizes e Bases da Educação Nacional or $2^{\text {nd }} \mathrm{LDB}$ ) mandated that the government decrease relative spending on secondary education, since the wealthier classes were more interested in ensuring higher investments in primary and tertiary education rather than expanding secon- 
dary education to the masses. ${ }^{1}$ Thus even if we assume that the database is trustworthy; nevertheless, the evidence is not convincing.

It is difficult to define what "primary" and "secondary education" means in Wjuniski (2013), since the $2^{\text {nd }}$ LDB reorganized schooling levels in 1971. Roughly speaking, the $2^{\text {nd }} \mathrm{LDB}$ doubled the number of years of compulsory schooling from four to eight years. The previous four-year ensino primário (elementary school) was replaced by the eight-year ensino de primeiro grau. Therefore, one cannot treat the latter as "primary education", since the 8 -year level created by the $2^{\text {nd }}$ LDB merged primary and lower secondary schooling levels according to the most common usage of the terms. In line with this, the former seven-year ensino médio (middle school) was replaced by the three-year ensino de segundo grau (high school). All statistics followed the regulatory change, creating challenges for constructing a continuous data series. Although both Maduro (2007) and Wjuniski (2013) acknowledge the problem, the latter runs econometric tests using that database. As a predictable consequence, he finds structural breaks in both "primary" and "secondary" levels for years around 1971. I argue that the breaks found close to 1971 were to a large extent a result of the change in the grade configuration rather than a consequence of a weaker position of secondary education among government priorities. In other words, previous work did not fully consider the effects of the $2^{\text {nd }} \mathrm{LDB}$ on the data found at the AEBs. In a nutshell, first I raise questions concerning the available database, which is far from being the proper one if the objective is to run structural break tests. Secondly, even if one assumes that the database is reliable, it does not mean there was an actual decrease in the resources devoted to the secondary school students. Therefore, it is not possible to conclude that there was resource misallocation that harmed the expansion of secondary education.

A word of caution: I decided to keep the original series span (1932-2004) rather than update the data to include the most recent education spending data available. There are several gaps in the original data sources and hence more complete research on historical education data in Brazil is necessary. This is just the first step in the research agenda on the construction of educational datasets in Brazilian economic history.

This work is divided into five sections. The next section provides a literature review on the political economy of education in post-1930 Brazil. In the third section, I discuss the effects of the $2^{\text {nd }} \mathrm{LDB}$ in enrollment and education spending data. I discuss data problems and the limitations of structural break tests on education spending data presently available in Brazil. The article ends with some final remarks and implications for future studies.

\footnotetext{
${ }^{1}$ Most translations to English refer to the $2^{\text {nd }}$ LDB as "Law of Directives and Bases". I decided to use a more explanatory translation.
} 


\section{LITERATURE REVIEW: EDUCATION IN POST-1930 BRAZIL}

In 1930, illiteracy represented around 60 percent of the Brazilian adult population, whereas that figure was about 15 percent in 2000 (Astorga et al.., 2005; Valle Silva, 2008). Although there has been a substantial increase in schooling, the country still possessed a high illiteracy rate at the end of the century in comparative terms, which reveals "the low priority historically given to basic education in Brazil" (Valle Silva, 2008). In terms of average years of schooling, Brazilian adults do not fare better than countries such as Zimbabwe: approximately 7.8 years (Barro \& Lee, 2013). Brazil had nearly universalized primary education by 2000, but the performance of Brazilian students in international tests such as PISA shows that the country still has a long way to go to achieving world-class standards.

Among the reasons provided in the literature to explain underdevelopment of the Brazilian educational system, most scholars present some sort of political economy argument. According to Plank (1996) and Plank et al.. (1996), elite private interests often superseded public ones in the implementation of education policies in post-1930 Brazil. Kosack (2012) argued that the dominant coalition counted on a cross-class alliance that favored the expansion of primary schooling between 1930 and 1961. According to this narrative, after the instability of the 1961-1964 period, Brazil entered an elite-biased phase under the military government that benefited the expansion of universities. On the other hand, Kang $(2011,2017)$ argues that federal governments did not give priority to primary education even before the military rule. Primary education was the responsibility of subnational governments, but tax revenues were concentrated in the hands of the federal government. However, most federal governments did not have any interest in helping states finance the expansion of mass education even prior to 1964. Ansell (2010) argued that under different political regimes, the maintenance of a semi-autarkic strategy of import-substituting industrialization for several decades since the 1930s created barriers to the expansion of mass education in Brazil. In turn, Brown (2002) asserted that the pattern of education spending changed towards primary schooling after the end of the military rule in 1985 .

Wjuniski (2013) also advances a political economy explanation for the Brazilian educational backwardness, stressing the role of the Second National Education Regulatory Framework ( $\left.2^{\text {nd }} \mathrm{LDB}\right)$. The $2^{\text {nd }} \mathrm{LDB}$ was enacted by the military government in 1971. Under the influence of the human capital approach, the military government would have put forward educational reforms in order to achieve higher productivity levels. In that context, the $2^{\text {nd }} \mathrm{LDB}$ would have dismissed secondary education, which "should be withdrawn as a public good, being gradually replaced by loans for students" (Wjuniski, 2013, p. 153). ${ }^{2} \mathrm{He}$ also indicates that article 63 of the $2^{\text {nd }}$ LDB clearly stated that objective. According to this perspective, the reasons for neglecting secondary education are twofold. First, Brazilian elites are in-

\footnotetext{
${ }^{2}$ Clearly the author is not using the microeconomic concept of "public good".
} 
terested in more investments towards public higher education rather than increasing the financial support for public secondary education. The latter level would not need public support, as there were private options available. ${ }^{3}$ Second, the working class should not have more than "minimum qualification", as this could increase "the possibility of contestation of the regime" (Wjuniski, 2013, p. 153). Given the reasons stated above, primary and tertiary education were government priorities, which left secondary education as a low priority.

Despite the qualitative argument having some plausibility, that reasoning runs counter the arguments of other scholars such as Schwartzman (2004) and Valle Silva (2008). They both agree that primary education was not a priority from the early 1930 s to the end of the century, i.e., for nearly 70 years. In the early 1970 s, the plans of the military government seemed "to favor continuing emphasis upon secondary and university enrollment, without sensibility to the distributional implications of such a structure" (Fishlow, 1972, p. 402). Indeed, the Constitution predicted that the free secondary and higher school system would be replaced by loans requiring later payments, but that was never put into practice (Mattos, 1988). Nonetheless, Wjuniski (2013) goes a step further: "as will be clear from the quantitative data, the expenditure allocation of the government followed exactly this policy, with increases in primary and tertiary expenditure, and a huge reduction in secondary investments" (Wjuniski, 2013, p. 154). Therefore, he claims there is quantitative evidence that investments in secondary education suffered a relative decrease. I argue that existing data does not allow us to draw that conclusion. The $2^{\text {nd }}$ LDB had a more important effect than the aforementioned one. It changed the grade-span configuration of schooling levels, leading to a break in the education spending series that has little (if anything) to do with changes in the government's priorities concerning schooling levels. I rather argue that post-1930 Brazil seems to have experienced a disturbing continuity in educational policies up to the mid-1980 s (at least in financial and expenditure aspects).

\section{EDUCATION DATA AND THE 2ND LDB (1971)}

The major change of the $2^{\text {nd }} \mathrm{LDB}$ involved reorganizing the existing grades in different educational stages. The $2^{\text {nd }}$ LDB increased the first schooling level an additional four grades, unifying the former primary and lower secondary levels. As a corollary, the lower secondary was separated from the upper secondary level. Therefore, there was a grade redistribution among different educational stages, even

\footnotetext{
${ }^{3}$ An idea that resembles Hirschman (1970)'s discussion on "voice and exit". This argument has been recently revived by the political science literature on collective skills policies in developed countries (see Busemeyer \& Iversen, 2014). ${ }^{4}$ The whole argument seems to be a version of an "ends against the middle" situation, in which the poor
and the rich allies against the middle class. See Epple and Romano (1996).
} 
though the total number of schooling years did not change. Next I present each educational stage through its official name in Brazilian regulatory laws, providing the English translations next to them in parentheses reflecting the following official UNESCO categories: primary education for ISCED1, lower secondary for ISCED2, upper secondary for ISCED3, and tertiary for ISCED 4 (UNESCO, 2012).

Prior to 1971, the formal education system was divided into the following three levels.

1. ensino primário (primary education): comprised of pré-primário (pre-primary), primário fundamental comum (regular primary), primário fundamental supletivo (equivalency) and primário complementar (supplementary). The standard primary education had four to six grades and was compulsory under national regulations for children between 7 and 11 years old before 1971. Most schools offered only four grades, so it is reasonable to assume that this level was expected to be completed when the child was around 10 years old.

2. ensino médio (lower and upper secondary education): divided into different tracks: the academic ensino secundário; the pedagogic ensino normal; and the professional ensino técnico (VET). The latter was subdivided into several branches (industrial, commercial, agricultural, etc.). All types of ensino médio had two stages, whose labels varied depending on the branch. In the academic secondary education, the first stage was called ensino ginasial (lower secondary school) and was comprised of four grades. The second one was called ensino colegial (upper secondary school)..$^{5}$ The colegial required three grades to be completed. Therefore, students were expected to complete the ensino médio when they were approximately 17 years old.

3. ensino superior (tertiary education): in order to get the degree, the student was expected to spend four to six years in school.

The $2^{\text {nd }}$ LDB enacted in 1971 changed the grade span configuration, essentially redistributing the grades. Under the new regulatory framework, the school system was divided into three levels:

1. ensino de primeiro grau (primary plus lower secondary), comprised of eight grades, was the result of the merge between the ensino primário and the first stage of the ensino médio;

2. ensino de segundo grau (upper secondary), comprised of three grades, which was the upper secondary school (the second stage of the ensino médio).

3. ensino de terceiro grau (tertiary), the new name for the ensino superior.

Table 1 summarizes the changes from the $2^{\text {nd }}$ LDB. Both Maduro (2007) and Wjuniski (2013) acknowledge these modifications, but the latter did not take full account of the effects of those changes on enrollment and expenditure data. The AEBs present the data in accordance with the law enforced at the time. For instance, the enrollment data presented for 1970 in the AEB 1972 divided the figures in

\footnotetext{
${ }^{5}$ The colegial provided two options for the students: they could opt for either the ensino clássico (classical education) or the ensino científico (scientific education).
} 
ensino primário and ensino médio, while later AEBs used the categories defined by the $2^{\text {nd }} \mathrm{LDB}$ (primeiro grau and segundo grau). Therefore, it would be possible to construct a complete series for the so-called primeiro grau, comprised of eight grades, only if there were a dataset on enrollments for the first stage of ensino médio in the period prior to 1971. That was not the case in previous works: the AEBs did not provide disaggregated data for each of the two stages of the pre-1971 ensino médio. ${ }^{6}$ The Appendix of Maduro (2007) presents data on enrollments in the ensino primário for the pre-1971 period and primeiro grau data for the post-1971 period. As a result, his series should present a discontinuity in 1971. Nonetheless, it was not clear how the author presented a graph with no discontinuities. After electronic correspondence with Paulo Maduro, I had access to his original files, which contained the data he used to construct his continuous series. There are few differences between his data and the information I collected from sources of the Ministry of Education and Culture other than the AEBs. In the Appendix of this paper, I present both Maduro's (2007) original data (which is not available in his 2007 work) and my enrollment series. Even though there was a way to tackle this problem in the case of enrollments, the problem is much more challenging regarding expenditure data.

Table 1: Brazilian schooling levels, before and after the $2^{\text {nd }}$ LDB, 1971

\begin{tabular}{|c|c|c|}
\hline Grade & pre-1971 & post-1971 \\
\hline 1 & \multirow{4}{*}{$\begin{array}{c}\text { ensino primário } \\
\text { (primary) }\end{array}$} & \multirow{8}{*}{ ensino de primeiro grau (primary + lower secondary) } \\
\hline 2 & & \\
\hline 3 & & \\
\hline 4 & & \\
\hline 5 & \multirow{7}{*}{$\begin{array}{l}\text { ensino médio } \\
\text { (secondary) }\end{array}$} & \\
\hline 6 & & \\
\hline 7 & & \\
\hline 8 & & \\
\hline 9 & & \multirow{3}{*}{ ensino de segundo grau (upper secondary) } \\
\hline 10 & & \\
\hline 11 & & \\
\hline & $\begin{array}{c}\text { ensino superior } \\
\text { (tertiary) }\end{array}$ & ensino de terceiro grau (tertiary) \\
\hline
\end{tabular}

Source: Brazilian statistical yearbook, IBGE.

\section{EDUCATION SPENDING AND STRUCTURAL BREAKS}

Despite all the difficulties given the 1971 regulatory change, Maduro (2007) also constructed a dataset on education spending. Although he did not have figures

\footnotetext{
${ }^{6}$ There is an exception: one of the tables of the 1980 AEB presents enrollment data from 1962 onwards using the post-1971 classification.
} 
for the whole period, the author applied interpolation techniques to complete the missing data. Frankema (2009) also collected education spending data compiled in UNESCO reports, but only for a few years. There are some differences between the two sources, but Wjuniski (2013) applied his tests using the former's data. ${ }^{7}$ We followed all procedures described in Wjuniski (2013) and our results are almost identical to the ones he found (see Figures 1 and 2). Details are also found on the Appendix.

The econometric procedure is correct, but this is not my major contention here. As mentioned earlier, my dissension is twofold. First, I have doubts over whether the data is reliable enough to apply a structural break test. Second, even if data is sound and there was a structural break around 1971 according to any methodology, it does not follow that the Brazilian government underinvested in secondary education from 1971 onwards.

\section{Is the spending data reliable?}

The $2^{\text {nd }} \mathrm{LDB}$ change requires attention to data problems. Unfortunately, there are no estimates of expenditures per grade, which would allow us to construct a correct and continuous data series for each level of schooling during the entire period from 1933 to 2004. Dealing with spending data is more challenging than dealing with enrollments. There is no way of constructing a continuous data series with the education spending data presently available.

Maduro (2007) asserts that he does not have complete data on educational spending per schooling level for all years. Although it is not worth repeating all the explanations provided there, we could consider a few examples. For instance, there is education expenditure data as a proportion of GDP summing up all government and schooling levels for most years, except for 1950, 1953, 1955, 1975-79, and 1991-93. As regards spending by different government levels, there were several missing lines in the database between 1971 and 1985. To estimate the spending of municipalities for that period, the author took the 1986 data and assumed the proportion of spending in each schooling level in the periods 1971-74 and 1980-85 were the same as 1986. For the states, he used the distribution of states' education spending in 1984 and assumed that structure prevailed for the states' expenditures on education in the periods 1971-74 and 1980-83. Fortunately, he had more data for the federal expenditures on education by schooling level, even though there were some empty spaces in the series. He used similar ways to fulfill the gaps in the rest of the database.

Those problems have important consequences. The interpolation techniques adopted probably have smoothing effects on data compared to what actually occurred (which is what we do not know). Smoothing the series might not allow detection of structural changes if there were any in the interpolated segments of the

\footnotetext{
${ }^{7}$ These divergences deserve a thorough investigation, but this is not the objective of this paper.
} 
series. Smoothing flows might not be a big deal in order to compute human capital stocks bearing in mind long-run growth empirics, as Maduro (2007) intended, inasmuch as fluctuations in the actual data tend to compensate each other in the long run. However, since structural break tests largely depend on lagged data, data smoothing seems to be a major problem for Wjuniski (2013).

\section{If the data is sound, what about structural break tests?}

If we ignore data problems and assume that they are reliable, what is left? I argue that even in this situation there are major problems. Assume the data is sound enough. Bearing in mind the $2^{\text {nd }} \mathrm{LDB}$ grade span change, it is hard to say what 'secondary education' means in this context: the spending series represents expenditures on a seven-year secondary education, named ensino médio prior to 1971, while the series continues with data representing spending on three-year upper secondary education, the segundo grau. Therefore, it was natural to expect a downward shift in the amount of resources if the number of grades decreased by more than a half. Consequently the same can be asserted of the first schooling level: the education spending series refers to a four-grade primary education (ensino primário) until 1971, whereas the data after 1971 represents the expenditures on the eighth-grade primary plus lower secondary level, the primeiro grau. ${ }^{8}$ This explains how spending in the first schooling level shifted after 1971. Therefore, we should expect to find structural breaks in 1971 even if the government did not change at all its priorities in terms of education spending.

Figure 1: Bai-Perron structural breaks in educational expenditures on primary education as a proportion of GDP, 1933-2004, Source: Maduro (2007); Wjuniski (2013).

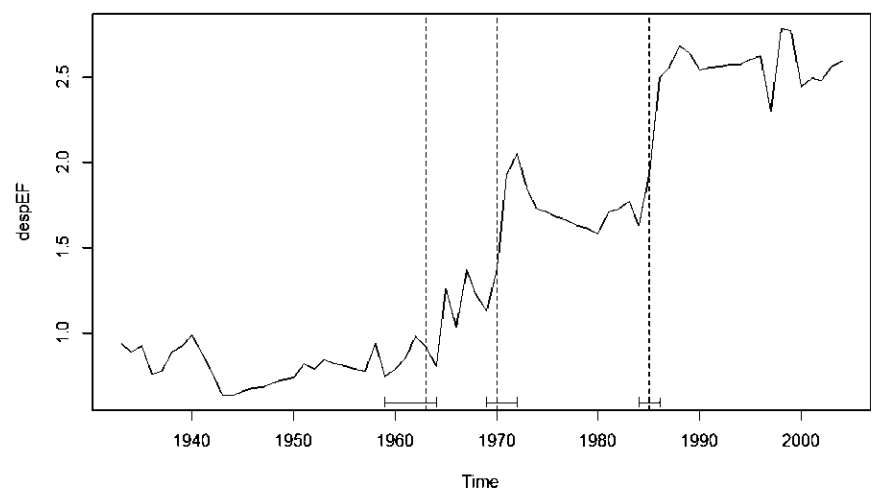

\footnotetext{
${ }^{8}$ Maduro (2007) already expected that there would be a spending shift with the change in the grade span configuration: "O ensino de $1^{\circ}$ grau compreendia as oito primeiras séries, enquanto que o então fundamental compreendia apenas as primeiras quatro séries; já o ensino de $2^{\circ}$ grau era composto por três séries, enquanto que o ensino médio possuía sete séries. Destarte, era esperado que a distribuição dos gastos se alterasse" (Maduro, 2007, p. 8).
} 
Figure 2: Bai-Perron structural breaks in educational expenditures in secondary education as a proportion of GDP, 1933-2004. Source: Maduro (2007); Wjuniski (2013).

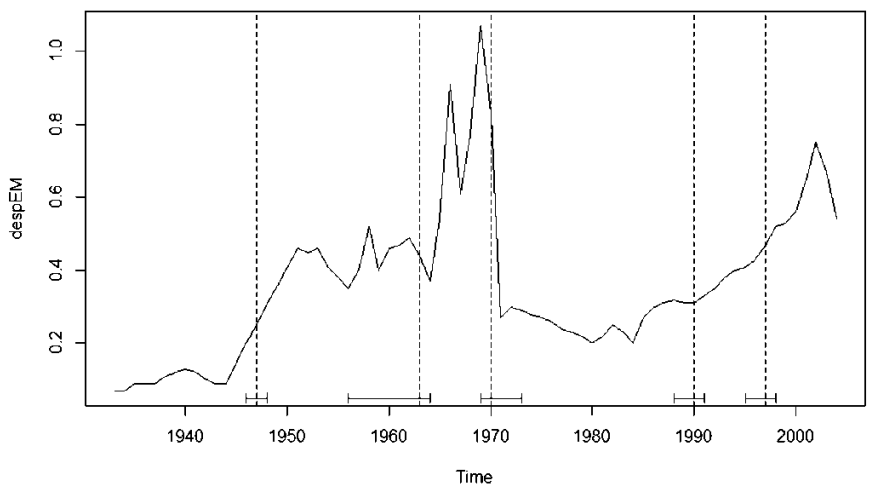

Discussion of structural breaks in the time series often refers to tests on parameter stability (Stock, 1986). The literature on multiple structural breaks was spurred by the research of Bai and Perron $(1998,2003)$, which developed a relatively general model of detecting multiple shifts in linear models estimated through least squares, permitting that not all parameters are subject to change. If a structural break refers to a change in parameter stability, not finding such a change would be an odd result in our case. The series of education spending as a proportion of the GDP is expected to suffer an upward shift when the number of students also increased considerably. The $2^{\text {nd }}$ LDB just redistributed the number of students and labeled them differently: a portion of what once was ensino médio became primeiro grau, creating the false impression that there was significant modification in the distribution of resources.

To clarify my point, the number of students in the pre- 1971 four-year primary level was 12,812,029 in 1970. A year later, the figures for the eight-year primeiro grau level was $17,266,093$. Therefore, it is not surprising that the amount of resources devoted to roughly 17.3 million students is higher than the amount spent on around 12.8 million pupils a year earlier - a difference that is attributable to a large extent to a label change. Therefore, the structural break found around 1971 is due to the difference in the number of pupils caused by the $2^{\text {nd }} \mathrm{LDB}$ grade span reconfiguration.

There is one more piece of information supporting the contention just raised. Maduro (2007) has estimates for expenditure per pupil as a proportion of per capita GDP. These estimates reinforce our point that there was not an actual structural break around 1971, although one must bear in mind that even those estimates have the same issues as those regarding the total spending variable. Applying the Bai-Perron methodology to the expenditure per primary education student series, we found only two structural breaks along the series: 1941 and 1985. Between 1941 and 1985, there is apparently a pattern of low spending per primary pupils compared to earlier and later periods. Concerning secondary education, we observed 
four structural breaks in the expenditure per pupil series. Although the test detected five distinct spending regimes, a visual analysis of the graph suggests that from 1947 onwards there is a clear decreasing tendency in the spending series. The different expenditure regimes detected only show increasingly lower patterns of spending per pupil. The major point here is that, considering expenditure per student, we did not find any structural break for both "primary" and "secondary education" around 1971. This is a surprising finding, since we are dealing with two different data series. It means that the expenditure per student regime in the 4-year primary school before 1970 was not statistically different from how much was spent on average with the representative pupil of the 8-year primeiro grau after 1971. As the question on data soundness remains, this is not strong evidence demonstrating that the pattern was the same before and after 1971, but not to find any break suggests that perhaps nothing changed, contradicting the findings of Wjuniski (2013).

Appendix A.2 of this paper presents details of the multiple structural break test of Bai and Perron (1998, 2003). The breakpoints in the expenditure per student series for "primary" and "secondary" levels are presented in Figures 3 and 4.

Figure 3: Bai-Perron structural breaks in educational expenditures per pupil on "primary education" as a proportion of per capita GDP, 1933-2004. Source: Maduro (2007)

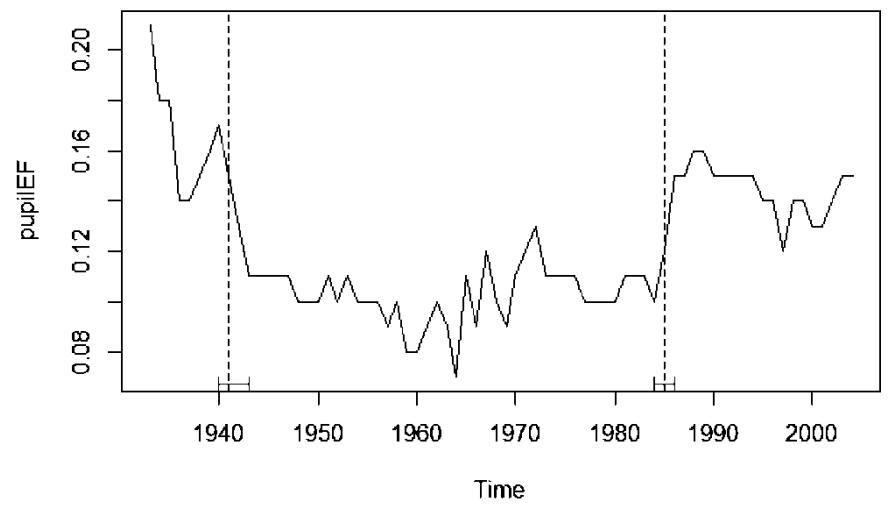

Figure 4: Bai-Perron structural breaks in educational expenditures per pupil on "secondary education" as a proportion of per capita GDP, 1933-2004. Source: Maduro (2007)

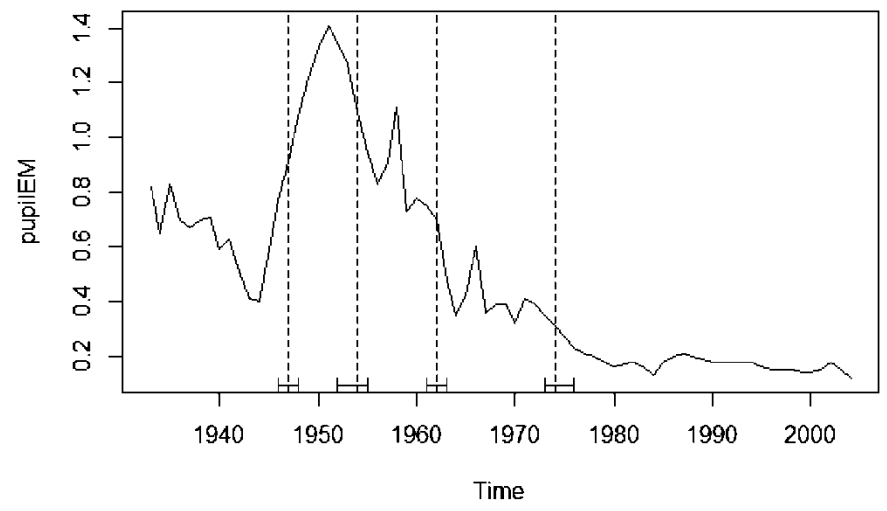




\section{FINAL REMARKS}

This article examined Wjuniski (2013) argument that spending on secondary education decreased after 1971 as government priorities changed. First I showed that the database constructed by Maduro (2007), though useful if the aim is to understand long-run growth empirics, is not reliable if one intends to run structural break tests. The author made several interpolations to complete the gaps in the data series, which tends to smooth the data.

The second contention holds even assuming that the data is sound. Even in this case, the breakpoints found around 1971 are expected, since we are actually dealing with two different series: before and after 1971. Since the $2^{\text {nd }}$ LDB changed the grade configuration in different levels, the structural break found in 1971 is a consequence of a measurement change. The breakpoint is found there because of the way the data series is constructed. Had Wjuniski (2013) used the expenditure per pupil series also provided by Maduro (2007), he would not have identified any break in 1971. Thus, the break is not a result of a lack of priority given to secondary education.

The findings of this paper have straightforward implications for the future research agenda. The major barrier to advance our knowledge on why Brazilian education remained poorly developed is a lack of data. This is a crucial issue, as historical approaches might be helpful to make us understand the persistence of the low performance of the Brazilian education system. Education has important consequences in terms of growth, poverty, inequality, and development (broadly speaking) in Brazil. Given the path dependent character of institutions and the persistence of dismal educational outcomes in the country, economic and social historians play an important role in providing further information on how Brazilian education fared throughout the $20^{\text {th }}$ century. Maduro (2007) and Wjuniski (2013), among others, began to construct and use datasets previously unexplored and deserve praise for their efforts. The limitations they faced are common in historical research, which should push the research agenda towards a collection of more accurate historical data.

\section{REFERENCES}

Ansell, B. W. (2010), From the Ballot to the Blackboard: The Redistributive Political Economy of Education, Cambridge: Cambridge University Press.

Antoshin, S., Souto, M. \& Berg, A. (2008), Testing for structural breaks in small samples, pp. 8-75, International Monetary Fund.

Astorga, P., Bergés, A. R. \& FitzGerald, V. (2005), 'The standard of living in Latin America during the twentieth century', The Economic History Review 58(4), 765- 796.

Bai, J. \& Perron, P. (1998), 'Estimating and testing linear models with multiple structural changes', Econometrica pp. 47-78.

Bai, J. \& Perron, P. (2003), 'Computation and analysis of multiple structural change models', Journal of Applied Econometrics 18(1), pp. 1-22.

Barbosa Filho, F. d. H. \& Pessôa, S. (2009), “Educação, crescimento e distribuição de renda: a experiên- 
cia brasileira em perspectiva histórica”, in F. Veloso, S. Pessôa, Henriques \& F. Giambiagi, eds, 'Educação básica no Brasil: construindo o país do futuro', Elsevier, pp. 51-72.

Barro, R. J. \& Lee, J. W. (2013), 'A new data set of educational attainment in the world, 1950-2010', Journal of Development economics 104, 184-198.

Brown, D. S. (2002), 'Democracy, authoritarianism and education finance in Brazil', Journal of Latin American Studies 34(1), 115-141.

Busemeyer, M. R. \& Iversen, T. (2014), 'The politics of opting out: explaining educational financing and popular support for public spending', Socio-Economic Review 12(2), pp. 299-328.

Epple, D. \& Romano, R. E. (1996), 'Ends against the middle: determining public service provision when there are private alternatives', Journal of Public Economics 62(3), pp. 297-325.

Fishlow, A. (1972), 'Brazilian Size Distribution of Income', American Economic Review 62(2), pp. 391 402.

Frankema, E. (2009), 'The expansion of mass education in twentieth century Latin America: a global comparative perspective', Revista de Historia Economica - Journal of Iberian and Latin American Economic History 27(3), pp. 359-396.

Hirschman, A. O. (1970), Exit, voice, and loyalty: Responses to decline in firms, organizations, and states, Harvard: Harvard University Press.

Kang, T. H. (2011), 'Descentralização e financiamento da educação brasileira: uma análise comparativa, 1930-1964', Estudos Econômicos (São Paulo) 41(3), pp. 573-598.

Kang, T. H. (2017), 'Educação para as elites, financiamento e ensino primário no Brasil, 1930-1964.', Latin American Research Review 52(1), pp. 35-49.

Kosack, S. (2012), The education of nations: How the political organization of the poor, not democracy, led governments to invest in mass education, Oxford: Oxford University Press.

Maduro, P. (2007), 'Taxas de matrícula e gastos em educação no Brasil', Master thesis - Fundação Getulio Vargas .

Mattos, P. L. C. L. de (1988), The politics of education funding in Brazil, 1964-1984, PhD thesis, London School of Economics and Political Science.

MEC (n.d.), Sinopse Estatística do Ensino, MEC.

Plank, D. (1996), The Means of Our Salvation: Public Education in Brazil, 1930-1995, Westview Press.

Plank, D. N., Sobrinho, J. A. \& Xavier, A. (1996), 'Why Brazil lags behind in educational development', in N. Birdsall \& R. Sabot, eds., Opportunity foregone: education in Brazil, IADB, pp. 117-146.

Schwartzman, S. (2004), "The challenges of education in Brazil”, in C. Brock \& Schwartzman, eds, The Challenges of Education in Brazil, Symposium Books Ltd, pp. 9-39.

Stock, J. H. (1986), “Unit roots, structural breaks and trends”, in R. F. Engle \& D. Mc - Fadden, eds, 'Handbook of Econometrics', Vol. 4 of Handbook of Econometrics, Elsevier, chapter 46, pp. 2739-2841.

UNESCO (2012), International Standard Classification of Education: ISCED 2011, UIS, Montreal, Quebec.

Valle Silva, N. d. (2008), "Brazilian society: Continuity and change, 1930-2000”, in Bethell, L. ed., Brazil Since 1930, Vol. IX of Cambridge History of Latin America, Cambridge University Press, pp. 455-544.

Wjuniski, B. S. (2013), 'Education and development projects in Brazil (1932-2004): political economy perspective', Revista de Economia Política 33(1), 146-165.

\section{A APPENDIX}

\section{A.1 Enrollment data}

A graph in Maduro (2007) shows primeiro grau and segundo grau enrollment rates for the entire 1933-2004 period. This graph is found in several other works 
on Brazilian education (Barbosa Filho \& Pessôa, 2009; Wjuniski, 2013). However, the data for primary plus lower secondary enrollments prior to 1971 are not available in this Appendix. Enrollment data for only upper secondary before 1971 also cannot be found there. Plotting the data available in this Appendix provides us the red curve in Figure 5. The sudden downward shift in the series reflects the $2^{\text {nd }} \mathrm{LDB}$ change. Indeed, before the shift we are dealing with the gross enrollment rates of the ensino primário, while the post-1971 data represents the gross enrollment rates of the ensino de primeiro grau.

Paulo Maduro kindly provided me his complete database, which contained data for the first eight years of schooling since 1933. This is possible because there is enrollment data available by grade, which enabled Maduro (2007) to calculate the enrollment rates for the first eight years of compulsory schooling from 1933 to 2004. In other words, he was able to add the enrollment data from both primary and lower secondary levels in the pre-1971 period and later build a continuous series using the primeiro grau enrollment data from 1971 onwards. That was the data used for the graph presented at Maduro (2007), also reproduced at Barbosa Filho \& Pessôa (2009) and Wjuniski (2013). His figures are approximately the same as those found in different sources from the Ministry of Education and Culture, which is the other curve plotted in Figure 5.

Figure 5: Gross enrollment rates at ensino primário (1933-1970),

ensino de primeiro grau (1971-2004) and primary plus lower secondary schooling (1933-2004).

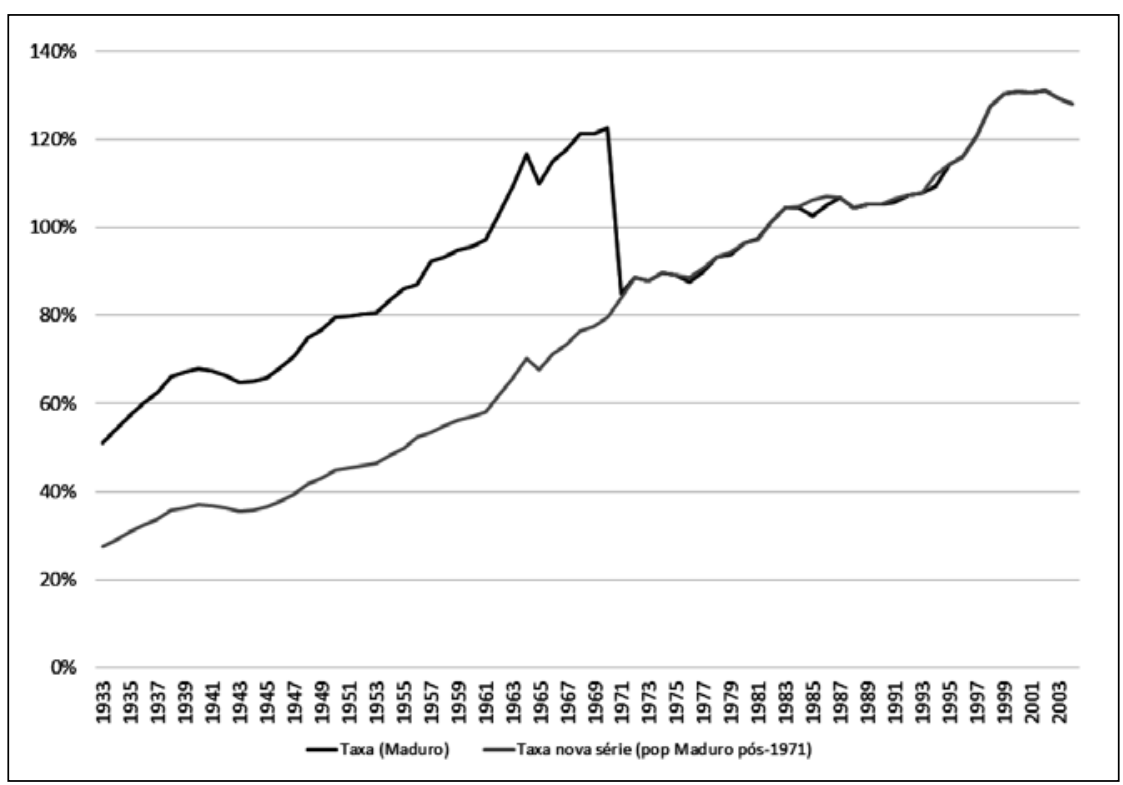

Source: Maduro (2007) and my own calculations based on mec1 


\section{A.2 Bai-Perron structural break test}

The methodology proposed by Bai and Perron $(1998,2003)$ considers multiple linear regression equations with $m$ breaks, i.e., $m+1$ regimes. The exposition here closely follows the seminal papers.

$$
y_{t}=x_{t}{ }^{\prime} \beta+z_{t}^{\prime} \gamma_{j}+u_{t} \quad\left(t=T_{j-1}+1, \ldots, T_{j}\right)
$$

for $j=1, \ldots, m+1$ and $T_{0}=0$ and $T_{\mathrm{m}+1}=T . y_{t}$ is the independent variable, $x_{t}$ and $z_{t}$ are the vector of covariates, while $\beta$ and $\gamma_{j}$ are the vectors of coefficients; and $u_{t}$ is the disturbance term. Since $\beta$ is not subject to shifts, the model is a more general version of structural change: if $x_{t}$ does not exist, we have a pure model. The indices $T_{1}, \ldots T_{m}$, which are the breakpoints, are treated as unknown. The model also allows for the inclusion of lagged dependent variables, as well as for heteroskedacity and serial autocorrelation.

There are two approaches to find the breakpoint. In the first one, the breakpoints $T_{1}, i=1$ are so that they minimize the sum of squared residuals (SSR):

$$
\sum_{n=1}^{m+1} \sum_{t=T_{i-1}+1}^{T_{i}}\left[y_{t}-x_{t}^{\prime} \beta-z_{t}^{\prime} \gamma_{j}\right]^{2}
$$

In the second version, there is a sequential process of determining breakpoints. The first break, chosen through the SSR, creates two partitions. The same procedure is applied for each partition, and so forth.

Specifications according to Wjuniski (2013) were followed: minimum interval of 10 percent of the series ( 7.2 years) and maximum of five breakpoints. I ran the tests using the package "strucchange" at $\mathrm{R}$. This package automatically provides information criteria for the definition of the number of breaks. Changing parameters do not change our main conclusions. ${ }^{9}$

Figures 1 and 2 are just the results found out by Wjuniski (2013) for the series on education spending as a proportion of GDP (by level), despite that it actually contains two different series each. Figures 3 and 4 present the breakpoints in the series of education spending per student as a proportion of per capita GDP for the primary and secondary levels respectively. Despite that the "primary" and "secondary" definition is inaccurate, the stability of the series is noteworthy given the changes entailed by the $2^{\text {nd }} L D B$.

\section{(c) (1)}

\footnotetext{
${ }^{9}$ I could have applied the small sample version of the Bai-Perron test, as proposed by Antoshin et al.. (2008), but that would not change the major arguments of this paper.
} 